УДК 616-022.7/.9-06:616.3-085.322-053.2

DOI 10.11603/24116-4944.2019.1.10178

\author{
๑ О. М. Шульгай${ }^{1}$ А. Б. Кабакова ${ }^{2}$, О. М. Мочульська ${ }^{1}$ А.-М. А. Шульгай ${ }^{1}$ \\ ${ }^{1}$ ДВНЗ «Тернопільсъкий державний медичний університет \\ ілені І. Я. Горбачевсъкого МОЗ України» \\ ${ }^{2}$ Тернопільсъка обласна дитяча клінічна лікарня
}

\title{
ЗАСТОСУВАННЯ РОСЛИННИХ ПРЕПАРАТІВ У ЛІКУВАННІ ПАРАЗИТОЗІВ У ДІТЕЙ З КОМОРБІДНОЮ ПАТОЛОГІЕЮ ТРАВНОЇ СИСТЕМИ
}

\begin{abstract}
Мета дослідження - визначити ефективність рослинного препарату у вигляді сиропу в лікуванні паразитозів у дітей різного віку з коморбідною патологією органів травлення.

Матеріали та методи. Обстежено 48 дітей віком від 3 до 14 років з паразитозами, які зверталися за медичною допомогою до гастроентеролога в Тернопільську обласну дитячу клінічну лікарню з приводу патології травної системи.

Результати дослідження та їх обговорення. В обстежених дітей виявлено такі паразитози, як лямбліоз, аскаридоз та ентеробіоз. Серед коморбідної патології в більшості пацієнтів діагностували функціональні розлади гепатобіліарної системи - диссрункцію жовчного міхура та дисфункцію сфінктера Одді. 3 метою дегельмінтизації як антипаразитарний засіб було застосовано рослинний препарат у вигляді сиропу, який містить екстракти п'яти рослин, а саме: насіння гарбуза, полину гіркого, чебрецю звичайного, листя волоського горіха та часнику. В процесі дослідження доведено клінічну ефективність рослинного препарату при паразитозах у дітей різного віку з коморбідною патологією травної системи, а також доцільність і безпечність його використання при даній патології.

Висновок. Рослинний препарат у вигляді сиропу, який містить екстракти п'яти рослин, а саме: насіння гарбуза, полину гіркого, чебрецю звичайного, листя волоського горіха та часнику, є ефективним антипаразитарним засобом при лікуванні паразитозів у дітей різного віку з коморбідною патологією органів травлення.
\end{abstract}

Ключові слова: паразитози; діти; коморбідна патологія; рослинні препарати.

ПРИМЕНЕНИЕ РАСТИТЕЛЬНЫХ ПРЕПАРАТОВ В ЛЕЧЕНИИ ПАРАЗИТОЗОВ У ДЕТЕЙ С КОМОРБИДНОЙ ПАТОЛОГИЕЙ ТРАВНОЙ СИСТЕМЫ

Цель исследования - определить эфффективность растительного препарата в виде сиропа в лечении паразитозов у детей разного возраста с коморбидной патологией органов пищеварения.

Материалы и методы. Обследовано 48 детей в возрасте от 3 до 14 лет с паразитозами, которые обращались за медицинской помощью к гастроэнтерологу в Тернопольскую областную детскую клиническую больницу по поводу патологии пищеварительной системы.

Результаты исследования и их обсуждение. У обследованных детей выявлено такие паразитозы, как лямблиоз, аскаридоз и энтеробиоз. Среди коморбидной патологии у большинства пациентов диагностировали функциональные расстройства гепатобилиарной системы - дисфункцию желчного пузыря и дисфрункцию сфринтера Одди. С целью дегельминтизации в качестве антипаразитарного средства был применен растительный препарат в виде сиропа, который содержит экстракты пяти растений, а именно: семян тыквы, полыни горькой, чабреца обыкновенного, листьев грецкого ореха и чеснока. В процессе исследования доказана клиническая эфффективность растительного препарата при паразитозах у детей разного возраста с коморбидной патологией пищеварительной системы, а также целесообразность и безопасность его использования при данной патологии.

Вывод. Растительный препарат в виде сиропа, который содержит экстракты пяти растений, а именно: семян тыквы, полыни горькой, чабреца обыкновенного, листьев грецкого ореха и чеснока, является эфрфективным антипаразитарным средством при лечении паразитозов у детей разного возраста с коморбидной патологией органов пищеварения.

Ключевые слова: паразитозы; дети; коморбидная патология; растительные препараты.

APPLICATION OF THE HERBAL MEDICATION IN TREATMENT OF PARASITOSIS IN CHILDREN WITH COMORBID PATHOLOGY OF THE DIGESTIVE SYSTEM

The aim of the study - to determine the effectiveness of the herbal medication in a form of syrup in treatment of parasitosis in children at different age groups with the comorbid pathology of a digestive system.

Materials and Methods. 48 children aged from 3 to 14 years with parasitosis were examined, who applied for medical aid to the gastroenterologist at Ternopil Region Children's Clinical Hospital with the pathology of a digestive system.

Results and Discussion. Giardiasis, ascariasis and enterobiasis were detected in examined children. Among the comorbid pathology of a digestive system in most of patients, the functional disorders of a hepatobiliary system such as gall bladder dysfunction and Oddi's sphincter dysfunction were diagnosed. In order to deworming as an anti-parasitic agent, we used the herbal medication in the form of a syrup containing extracts of five plants, that is: pumpkin seeds, wormwood, common thyme, walnut leaves and garlic. Clinical efficacy of the herbal medication at parasitosis in children of different age groups with the comorbid pathology of a digestive system's has been proven during research, as well as expediency and safety of its use at this pathology.

Conclusion. The herbal medication in a form of a syrup containing extracts of five plants, that is: pumpkin seeds, wormwood, common thyme, walnut leaves and garlic, are effective anti-parasitic agent in treatment of parasitosis in children at different ages with the comorbid pathology of a digestive system.

Key words: parasitosis; children; comorbid pathology; herbal medication. 
ВСтУП. Паразитози в дітей - досить актуальна та серйозна проблема, з якою сьогодні стикається більшість лікарів, починаючи з первинної ланки. За даними Всесвітньої організації охорони здоров'я, гельмінтози займають 3-тє місце серед інсрекційних захворювань [1], загрожуючи здоров'ю дітей. Відомо про паразитування в організмі людини близько 350 видів гельмінтів, які патологічно впливають на стан шлунково-кишкового тракту (ШКТ) та організм у цілому. В Україні зустрічається приблизно 30 видів паразитів, що мають значну інвазивність і канцерогенність, причому близько 80 \% хворих на гельмінтози - це саме дитяче населення [2-4]. Джерел зараження гельмінтами і найпростішими дітей є безліч, а саме: громадський транспорт (сидіння, поруччя), домашні тварини (собаки, коти, гризуни), громадські місця (дитячі садки, школи, поліклініки, туалети, кафе, пісочниці), гроші, засоби спільного навчання та ігор (телефон, комп'ютер), вода 3-під крана чи іншого неперевіреного джерела, погано оброблені продукти харчування [5].

Причинами наявності проблеми паразитозів саме в дитячого населення, крім значної розповсюдженості й контагіозності гельмінтозів, $є$ відсутність настороженості та недостатня обізнаність щодо негативних впливів на стан здоров'я дитини, відсутність патогномонічних (тобто притаманних саме даній патології) клінічних ознак. Гельмінти і найпростіші алергізують організм дитини, викликають пригнічення імунного захисту, ураження травної, дихальної систем, системи крові, функціональні порушення в роботі різних внутрішніх органів, появу авітамінозу, анемії та астенізацію за рахунок продуктів своєї життєдіяльності, іноді за досить тривалий період свого перебування в організмі, а також внаслідок постійної реінвазії [6]. Найчастіше з гельмінтозів у дітей діагностують аскаридоз та ентеробіоз, а також ураження організму найпростішими - лямбліями. Дані паразити можуть виникати на фоні цілої низки захворювань шкТ, іноді маскуючи їх або ускладнюючи перебіг, тому питання лікування та профрілактики цієї патології в дітей різного віку є досить дискутабельним та при наявності коморбідної патології потребує постійного вдосконалення терапевтичних схем

Гельмінтози клінічно мають низку як загальних, так і більш специфрічних проявів. До загальних проявів належать: підвищення температури, головний біль, збільшення лімсратичних вузлів, які трактують як прояв вірусної інсекції; свербіж шкіри, лущення чи висипання на шкірі, що маскується під атопічний дерматит [7]; біль у м'язах, втомлюваність, зниження працездатності, сонливість вдень та неспокійний сон вночі, які інтерпретують як симптоми інтоксикації [8]. Крім того, діти з паразитозами зазвичай більш хворобливі, частіше звертаються за медичною допомогою 3 приводу гострих респіраторних захворювань, загострення хронічної патології. Звичайно ж, у лікаря повинен викликати сумнів діагноз атопічного дерматиту, при якому відсутні попередній обтяжений алергологічний анамнез та розбіжності за результатами лабораторних обстежень і проведення алергопроб. До більш специфічних проявів належать: біль чи відчуття дискоморорту в животі, нудота, переважно зранку, періодичне блювання, нестійкі випорожнення, слинотеча (симптом «вогкої» подушки) та бруксизм (скреготіння зубами) уві сні, періанальний свербіж, виражений неприємний запах з рота, зниження або втрата маси тіла [5].
Лікування паразитозів сьогодні включає не лише знищення паразита, але й ліквідацію тих наслідків, які відбулися в дитячому організмі в процесі його життєдіяльності [9]. Тому до схем лікування, крім антигельмінтних засобів, включають також ентеросорбенти, жовчогінні, бактерійні та десенсибілізувальні засоби. Але, на жаль, звичні антигельмінтні засоби мають низку побічних реакцій, не завжди вони є досить ефективними, а також не всі можна призначати дітям різного віку, особливо з коморбідною патологією. Тому на сьогодні досить широко застосовують рослинні засоби дегельмінтизації. Такі фрітопрепарати, що мають м'який терапевтичний ефект, використовують саме в тих випадках, коли звичні синтетичні засоби не можуть бути застосовані, а саме при коморбідній патології, або доповнюючи стандартне лікування, при цьому покращуючи його ефективність.

МЕТА ДОсЛІДЖЕННЯ - визначити ефективність рослинного препарату у вигляді сиропу в лікуванні паразитозів у дітей різного віку з коморбідною патологією органів травлення.

МАТЕРІАЛИ ТА МЕТОДИ. БУЛо обстежено 48 дітей віком від 3 до 14 років, які зверталися за медичною допомогою до гастроентеролога в Тернопільську обласну дитячу клінічну лікарню з приводу патології травної системи. За статтю серед них був 21 (43,8 \%) хлопчик та 27 (56,2 \%) дівчаток (рис. 1). Більшість обстежених дітей (68 \%) - жителі сільської місцевості (рис. 2). За віком серед усіх обстежених переважали діти від 4 до 8 років (тобто дошкільний та молодший шкільний вік), що становило $72,9 \%$.

У всіх цих дітей у результаті обстеження виявлено такі паразитози: у 29 (60,4 \%) - лямбліоз, у 6 (12,5\%) ентеробіоз, у 13 (27,1\%) - аскаридоз (рис. 3).

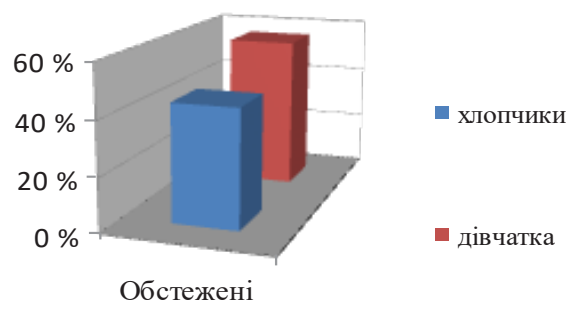

Рис. 1. Розподіл обстежених дітей за статтю.

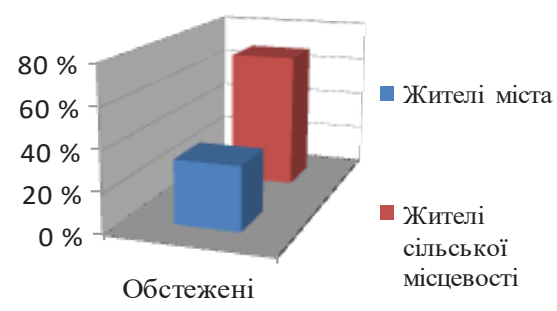

Рис. 2. Розподіл обстежених дітей за місцем проживання.

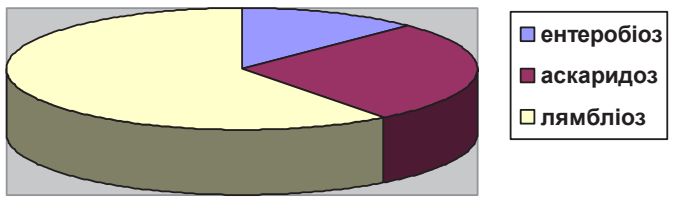

Рис. 3. Розповсюдженість паразитозів у обстежених дітей. 
Усі обстежені пацієнти, крім паразитозу, мали коморбідну патологію травної системи, причому в більшості (89,6 \%) переважали функціональні захворювання гепатобіліарної системи, або як основна патологія, або як супутня. Це пов'язано, по-перше, із значною розповсюдженістю даної патології саме в дитячому віці, а по-друге, 3 невчасною діагностикою та невідповідним лікуванням [10]. Саме при фрункціональних порушеннях травлення 3'являється можливість для розмноження та життєдіяльності паразитів. Діагноз встановлювали згідно із клінічною класифрікацією захворювань органів травлення відповідно до Міжнародної класифрікації хвороб 10-го перегляду та наказу МОЗ України № 59 «Про затвердження уніфрікованих клінічних протоколів медичної допомоги дітям із захворюваннями органів травлення».

Діагноз паразитозу було встановлено при виявленні яєць Ascaris lumbricoides (аскаридоз) чи цист Giardia intestinalis (лямбліоз) під час гельмінтологічного дослідження орекалій та яєць Enterobius vermicularis (ентеробіоз) за допомогою зіскобу. Контроль за проведеною ерадикацією здійснювали через 2 тижні після курсу лікування. Він передбачав 3-разове гельмінтологічне дослідження калу, причому лише у 2 (4,2%) дітей повторно виявлено яйця гельмінтів, оскільки не було дотримано схеми лікування. Усім дітям проведено ультразвукове дослідження органів черевної порожнини, під час якого оцінювали розмір, стан паренхіми печінки, ехогенність, наявність кальцинатів, кіст, з метою оцінки моторної фрункції жовчного міхура та тонусу сорінктерів біліарного тракту виконували динамічну ультразвукову холецистографрію з використанням холекінетичного сніданку, за потреби - ендоскопічне дослідження верхніх і нижніх відділів травного тракту (для виявлення коморбідної патології).

РЕЗУЛЬТАТИ ДОСЛІДЖЕННЯ ТА ЇХ ОБГОВОРЕНня. Серед функціональних захворювань гепатобіліарної системи в більшості пацієнтів діагностували дисфункцію жовчного міхура - у 29 (60,4 \%) дітей, у решти 19 (39,6 \%) диссункцію сфрінктера Одді. Інша патологія травного тракту розподілилася таким чином: у 2 (4,2\%) осіб діагностовано синдром подразненої товстої кишки, в 11 (22,9 \%) - хронічний гастродуоденіт, у 5 (10,4 \%) - фрункціональну диспепсію, в однієї дитини (2,1\%) виявлено активну виразку цибулини дванадцятипалої кишки, ще в однієї (2,1 \%) - хронічний ерозивний бульбіт (табл. 1).

Серед клінічних ознак, які було виявлено в обстежених дітей, незважаючи на вид паразитозу та характер коморбідної патології, переважали такі: біль у животі різної локалізації і характеру - в 46 (95,8 \%) хворих, відрижка (кислим чи повітрям) - у 13 (27,1\%), печія - у 5 (10,4\%), нудота - у 17 (35,4 \%), блювання - у 4 (8,3\%), зміни характеру випорожнень (закрепи чи проноси) - у 19 (39,6 \%), блідість та сухість шкіри - у 14 (29,2 \%), «тіні» під очима - у 16 (33,3 \%), періодичний сухий кашель, переважно вранці, - у 7 (14,6 \%), зниження апетиту чи перебірливість в їжі - у 29 (60,4 \%), неспокійний сон - у 18 (37,5\%), скреготіння зубами - у 8 (16,7\%), висипання на шкірі -у $3(6,25 \%)$. Лише у $23(47,9 \%)$ дітей спостерігали зміни в загальному аналізі крові у вигляді помірної еозинофрілії та зниження гемоглобіну й еритроцитів, у 5 (10,4 \%) пацієнтів із підтвердженим паразитозом еозинофріли в загальному аналізі крові взагалі були відсутні.

3 метою дегельмінтизації було застосовано рослинний препарат у вигляді сиропу, який містить екстракти п'яти рослин, а саме: насіння гарбуза, полину гіркого, чебрецю звичайного, листя волоського горіха та часнику. Дані рослини, крім антигельмінтної дії, сприяють виведенню токсичних речовин з організму та покращують роботу травної системи. Насіння гарбуза має прямий антигельмінтний вплив за рахунок вмісту кукурбітину, який паралізує гельмінтів, не даючи можливості рухатися, прикріплюватися до стінок кишки та розмножуватися, а також у результаті покращення моторики сприяє виведенню залишків паразитів та продуктів їх життєдіяльності фрізіологічним шляхом. Екстракт полину гіркого за рахунок вмісту активних речовин має жовчогінний ефект, стимулює секрецію шлункового соку та фрерментів підшлункової залози, покращує апетит. Антипаразитарний ефект екстракт полину має на гельмінти, особливо круглі (аскариди, гострики) та найпростіші (лямблії). Екстракт часнику, крім прямої антигельмінтної дії, за рахунок вмісту діалілу сульфріду, що має антибактеріальні властивості, пригнічує процеси гниття і бродіння в кишечнику та сприяє нормалізації мікрофолори. Також часник має жовчогінний ефект, за рахунок вмісту аліцину стимулює травлення та підвищує апетит. Екстракт чебрецю звичайного за рахунок активних речовин (ефірні олії) покращує процеси травлення, зменшує бродіння в кишечнику, стимулює апетит та має антипаразитарну дію. Екстракт листя волоського горіха впливає на обмінні процеси у тканинах паразитів, оскільки порушує утилізацію глюкози та знижує кількість глікогену в зрілих особин та їх личинок, він покращує апетит, нормалізує стан мікроорлори кишечника та має протизапальний ефект [1].

Сукупність перелічених властивостей рослин, що входять до складу даного препарату, різноплановість

Таблиця 1. Частота коморбідної патології в обстежених дітей

\begin{tabular}{|l|c|c||}
\hline \multicolumn{1}{|c|}{ Патологія травної системи } & \multicolumn{2}{c||}{ Кількість дітей } \\
\cline { 2 - 3 } & абсолютна & \% \\
\hline Дисфункція жовчного міхура за гіпокінетичним типом & 20 & 41,7 \\
\hline Дисфункція жовчного міхура за гіперкінетичним типом & 9 & 18,7 \\
\hline Диссункція сфрінктера Одді за біліарним типом & 13 & 27,1 \\
\hline Дисфункція сфрінктера Одді за панкреатичним типом & 6 & 12,5 \\
\hline Хронічний гастродуоденіт & 11 & 22,9 \\
\hline Функціональна диспепсія & 5 & 10,4 \\
\hline Синдром подразненої товстої кишки & 2 & 4,2 \\
\hline Активна виразка цибулини дванадцятипалої кишки & 1 & 2,1 \\
\hline Хронічний ерозивний бульбіт & 1 & 2,1 \\
\hline \hline
\end{tabular}


їх впливу на організм, відсутність токсичної дії на фрункціонування внутрішніх органів, особливо відсутність гепатотоксичного ефекту дозволили вважати його засобом вибору в дітей із паразитозами та коморбідною патологією травної системи.

Усі пацієнти з виявленим паразитозом (аскаридозом, ентеробіозом чи лямбліозом) на фроні коморбідної патології органів травлення приймали рослинний препарат у вигляді сиропу, що містить екстракти п'яти рослин 2 курси по 14 днів з 2-тижневою перервою в стаціонарі й амбулаторно. Дозу препарату призначали відповідно до віку: від 3 до 5 років - по 5 мл 2 рази на день за 15 хв до їди, від 5 до 12 років - по 5 мл 3 рази на день за 15 хв до їди, діти, старші 12 років, - по 10 мл 2 рази на день за 15 хв до їди. У перерві між прийманням антипаразитарного сиропу для нормалізації мікробіоценозу кишечника призначали бактерійні препарати. Препарат хворі приймали за згоди батьків та під їх наглядом. При застосуванні даного рослинного препарату не було відмічено погіршення самопочуття пацієнтів, він добре переносився, жодна дитина не відмовилася від його приймання. Незважаючи на мультикомплекс екстрактів рослин, що входять до складу препарату, та різноплановість дій на організм дитини, в пролікованих дітей не було відмічено жодного побічного ефректу під час чи після приймання сиропу, в тому числі алергічних реакцій.

Критеріями ефективності застосування даного рослинного препарату були позитивна динаміка клінічних симптомів (табл. 2), аналізу периферійної крові, копроскопії, зіскобу на ентеробіоз, повторне проведення ультразвукового дослідження органів та ендоскопії. При контрольних обстеженнях випорожнень та зіскобу на ентеробіоз уже на 14-й день приймання рослинного препарату в жодного пацієнта не було виявлено яєць гельмінтів чи найпростіших.

За результатами лікування було зроблено висновок не лише щодо антипаразитарних властивостей рослинного препарату, а також і стосовно його безпечного використання при наявності коморбідної патології травної системи. Через місяць спостереження при ультразвуковому дослідженні гепатобіліарної системи збільшення печінки зберігалося лише у 3 (6,25 \%) пацієнтів, змін ехогенності паренхіми печінки чи підшлункової залози, розширення жовчних ходів або потовщення стінок не було виявлено. Негативного впливу даного препарату на перебіг захворювань гастродуоденальної зони і товстої кишки не спостерігали, навіть при наявності деструктивних змін.

Таблиця 2. Динаміка клінічних симптомів ураження травного тракту в дітей (абс, \%)

\begin{tabular}{|l|c|c|c||}
\hline \multicolumn{1}{|c|}{ Клінічна ознака } & До лікування & $\begin{array}{c}\text { На 14-й день } \\
\text { лікування }\end{array}$ & $\begin{array}{c}\text { На 28-й день } \\
\text { лікування }\end{array}$ \\
\hline Біль у животі & $46(95,8)$ & $17(35,4)$ & 0 \\
\hline Відрижка & $13(27,1)$ & $5(10,4)$ & 0 \\
\hline Печія & $5(10,4)$ & $1(2,1)$ & 0 \\
\hline Нудота & $17(35,4)$ & $4(8,3)$ & 0 \\
\hline Блювання & $4(8,3)$ & 0 & $3(6,25)$ \\
\hline Зміни характеру випорожнень & $19(39,6)$ & $9(18,75)$ & $1(2,1)$ \\
\hline Блідість, сухість шкіри & $14(29,2)$ & $7(14,6)$ & $1(2,1)$ \\
\hline «Тні» під очима & $16(33,3)$ & $8(16,7)$ & 0 \\
\hline Сухий кашель & $7(14,6)$ & $1(2,1)$ & $2(4,2)$ \\
\hline Зниження (вибірковість) апетиту & $29(60,4)$ & $16(33,3)$ & 0 \\
\hline Неспокійний сон & $18(37,5)$ & $6(12,5)$ & $1(2,1)$ \\
\hline Скреготіння зубами & $8(16,7)$ & $3(6,25)$ & 0 \\
\hline Висипання на шкірі & $3(6,25)$ & $1(2,1)$ & \\
\hline \hline
\end{tabular}

ВИСновкИ. Зазначений рослинний препарат у вигляді сиропу, що містить екстракти п'яти рослин, є досить ефективним та безпечним засобом лікування паразитозів у дітей різного віку, що підтверджено результатами клінічного і лабораторного обстеження, в результаті його застосування покращилися самопочуття та якість життя пацієнтів. Багатофункціональна і синергічна дія рослинних компонентів даного препарату дала можливість обмежити додаткове приймання інших лікарських засобів, які зазвичай застосовують у комплексному лікуванні паразитозів у дітей.
ПЕРСПЕКТИВИ ПОДАЛЬШИХ ДОСЛІДЖЕНЬ. Оскільки проблема паразитозів у дітей залишається актуальною, а синтетичні антипаразитарні препарати $€$ досить агресивними, необхідно продовжити вивчення есрективності дії рослинних препаратів при лікуванні цієї патології, особливо за наявності супутньої патології органів травлення.

Конфрлікт інтересів. Автори заявляють про відсутність конфрлікту інтересів при підготовці даної статті.

\section{СПИСОК ЛІТЕРАТУРИ}

1. Практические вопросы диагностики и лечения гельминтозов у детей / О. Г. Шадрин, А. А. Ковальчук, С. В. Дюкарева, В. Н. Фисун // Здоровье ребенка. - 2015. - № 4 (64). - С. 7-10. doi: https://doi.org/10.22141/2224-0551.4.64.2015.75238
2. Печкуров Д. В. Глистные инвазии у детей: клиническое значение, диагностика и лечение / Д. В. Печкуров, А. А. Тяжева // Здоров'я України. - 2014. - № 3. C. $49-50$. 
3. Крамарьов С. О. Гельмінтози у дітей / С. О. Крамарьов, Л. В. Закордонець // Здоровье ребенка. - 2018. - Т. 13, № 3. - С. 79-86.

4. Растительные средства в терапии гельминтозов у детей / О. Г. Шадрин, А. А. Ковальчук, С. И. Герасимюк [и др.] // Педиатрия. Восточная Европа. - 2018. - Т. 6, № 1. - C. 198-203.

5. Майданник В. Г. Гельминтозы у детей / В. Г. Майданник, Н. В. Хайтович, Г. Г. Юхименко. - К. : Дорадо-Друк 2012. -601 c.

6. Шляхи корекції порушень функціонального стану шлунково-кишкового тракту при гельмінтозах у дітей / О. Г. Шадрін, А. А. Ковальчук, В. Н. Дюкарєва [та ін.] //

\section{REFERENCE}

1. Shadrin, O.G., Kovalchuk, A.A., Dukarev, S.V., \& Fisun, V.N. (2015). Prakticheskiye voprosy diagnostiki i lecheniya gelmintozov $u$ detey [Practical issues of diagnosis and treatment of helminths in children]. Zdorovye rebenka - Health of a Child, 4 (64), 7-10. doi: https://doi.org/10.22141/2224-0551.4.64.2015.75238 [in Russian].

2. Pechkurov, D.V., \& Tyazheva, A.A. (2014). Glistnye invazii u detey: klinicheskoye znacheniye, diagnostika i lecheniye [Worm infections in children: clinical significance, diagnosis and treatment]. Zdorovia Ukrainy - Health of Ukraine, 3, 49-50 [in Russian].

3. Kramarev, S.O., \& Zakordonets, L.V. (2018). Helmintozy u ditei [Helminthosis in children]. Zdorovye rebenka - Health of a Child, 13 (3), 79-86 [in Ukrainian].

4. Shadrin, O.G., Kovalchuk, A.A., Gerasimyuk, S.I., Turkin, Yu.V., \& Kodrul, Yu.V. (2018). Rastitelnyye sredstva $u$ detey $v$ terapii gelmintozov $u$ detey [Herbal remedies in the treatment of helminth infections in children]. Pediatriya. Vostochnaya Yevropa - Pediatrics. Eastern Europe, 6 (1), 198-203 [in Russian].

5. Maydannik, V.G., Khaytovich, N.V., \& Yukhimenko, G.G. (2012). Gelmintozy u detey [Helminthiasis in children]. Kiev: Dorado-Druk [in Russian].
Здоровье ребенка. - 2016. - № 7 (75). - C. 27-32. doi: http:// dx.doi.org/10.22141/2224-0551.7.75.2016.86720

7. Зайков С. В. Гельминтозы и аллергические заболевания / С. В. Зайков // Клінічна імунологія. Алергологія. Інфектологія. - 2009. - № 2. - С. 1-12.

8. Ершова И. Б. Неспецифические проявления гельминтозов у детей / И. Б. Ершова // Здоровье ребенка. - 2015. - № 8. - С. 45-50.

9. Майданник В. Г. Аскаридоз у детей / В. Г. Майданник // Здоров'я України. - 2012. - № 5. - С. 14-16.

10. Сорокман Т. В. Показники цитокінів у дітей із гепатобіліарною патологією, поєднаною 3 паразитозами / Т. В. Сорокман, Н. О. Попелюк, Л. В. Швигар // Гастроентерологія (Gastroenterology). - 2018. - Т. 52, № 1 - С. 26-29. doi: http://dx.doi.org/10.22141/2308-2097.52.1.2018.130776

6. Shadrin, O.H., Kovalchuk, A.A., Dukareva, V.N., Fisun, V.M., \& Basaraba, N.M. (2016). Shliakhy korektsii porushen funktsionalnoho stanu shlunkovo-kyshkovoho traktu pry helmintozakh $u$ ditei [Ways of correction of the functional disorders of gastrointestinal tract in children with helminthiasis]. Zdorovye rebenka - Health of a Child, 7 (75), 27-32. doi: http:// dx.doi.org/10.22141/2224-0551.7.75.2016.86720 [in Ukrainian].

7. Zaikov, S.V. (2009). Gelmintozy i allergisheskiye zabolevaniya [Helminthiasis and allergic diseases]. Klinichna immunolohiia. Alerholohiia. Infektolohiia - Clinical Immunology. Allergology. Infectology, 2, 1-12 [in Russian].

8. Ershova, I.B. (2015). Nespetseficheskiye proyavleniye gelmintozov u detey [Non-specific manifestations of helminthiasis in children]. Zdorovye rebenka - Health of a Child, 8, 45-50 [in Russian].

9. Maidannik, V.G. (2012). Askaridoz u detey [Ascaridosis in children]. Zdorovia Ukrainy - Health of Ukraine, 5, 14-16 [in Russian].

10. Sorokman, T.V., Popeliuk, N.O., \& Shvyhar, L.V. (2018). Pokaznyky tsytokiniv u ditei iz hepatobiliarnoiu patolohiieiu, poiednanoiu z parazytozamy [Indicators of cytokines in children with hepatobiliary pathology combined with parasitosis]. Hastroenterolohiia - Gastroenterology, 1 (52), 26-29 doi: http://dx.doi. org/10.22141/2308-2097.52.1.2018.130776 [in Ukrainian].

Отримано 19.02.19 